\section{Pleistocene Sea Levels possibly indicated by Buried Black Sediments in the Black Sea}

MODERN surface sediments containing $\mathrm{H}_{2} \mathrm{~S}$ are often coloured black by fine grained, iron monosulphide minerals such as mackinawite, $\mathrm{Fe}_{1+x} \mathrm{~S}$, and greigite, $\mathrm{Fe}_{3} \mathrm{~S}_{4}$. The black monosulphides are thermodynamically unstable, under $\mathrm{H}_{2} \mathrm{~S}$-rich sedimentary conditions, relative to the disulphide pyrite, $\mathrm{FeS}_{2}{ }^{1,2}$, which is not a black pigmenting agent. As a result, the black colour normally disappears with depth during diagonetic transformation to pyrite ${ }^{z, 3}$. In some situations, however, such as in older buried layers of the deep water sediments of the Black Sea, the black monosulphides persist.

Volkov ${ }^{4}$ has shown that the black sediment of the Black Sea, when compared with the more common lighter grey sediment, is characterizod by low concentrations of pyrite, lower total reduced sulphur, high concentrations of iron monosulphides, and very low dissolved $\mathrm{H}_{2} \mathrm{~S}$ in associated pore waters. He has suggested that this black sediment results from limited bacterial sulphate reduction during early diagenesis with insufficient hydrogen suiphide formed to enable complete transformation of black " $\mathrm{FeS}$ " to $\mathrm{FeS}_{\mathrm{g}}$. Recent analyses confirm these conclusions (see Table 1). Methods of determination of each constituent have been described previously ${ }^{2}$. Note that the total "reactive" iron content (pyrite iron plus HCl-(soluble iron) does not consistently differ between grey, pyritic sediment and black sediment. Thus the decrease in total reduced sulphur in the black layers must have been caused by a lower original production of $\mathrm{H}_{2} \mathrm{~S}$ by bacteria.

Limited $\mathrm{H}_{2} \mathrm{~S}$ production in anaerobic sediments and bottom waters is related primarily to (1) a low concentration of bacterially metabolizable organic matter, or (2) a low concentration of dissolved sulphate. Because the black layers of the Black Sea sediment are not distinctly different in organic carbon content from interbedded grey layers (see Table 1), barring such speculative factors as trace motal bactorial poisoning, the lowered $\mathbf{H}_{2} \mathrm{~S}$ production during deposition of the black layers must have been caused by a low concentration of dissolved sulphote in the overlying wator. In a low sulphate situation, diffusion of sulphate into sediments may be too slow to provide enough sulphur for the complete diagenetic transformation of iron monosulphides to pyrite.

Table 1. MEAStRED PARAMETERS FOR A CORE (1464-R) OF BHACK SEA

\begin{tabular}{|c|c|c|c|c|c|}
\hline \multirow[b]{2}{*}{$\begin{array}{l}\text { Sampling } \\
\text { depth ranye }\end{array}$} & \multicolumn{3}{|c|}{ BEDIMENT } & \multirow[b]{2}{*}{$\begin{array}{c}\text { "Ronctive" } \\
\text { Iron } \\
\text { (per cent) }\end{array}$} & \multirow[b]{2}{*}{$\begin{array}{c}\text { Organic } \\
\text { carbon } \\
\text { (per cent) }\end{array}$} \\
\hline & Colour & $\begin{array}{c}\text { Per cent } s \\
\text { Fes }+F^{\prime} e_{3} s\end{array}$ & 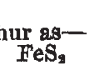 & & \\
\hline $\begin{array}{l}152-155 \mathrm{~cm} \\
157-159 \\
162-164 \\
166-168 \\
172-175 \\
181-185 \\
239-241 \\
247-249 \\
259-262 \\
270-272 \\
279-281 \\
284-287 \\
297-299 \\
305-307 \\
329-331 \\
341-348 \\
347-349 \\
362-364\end{array}$ & $\begin{array}{l}\text { Black } \\
\text { Black } \\
\text { Black } \\
\text { Grey } \\
\text { Grey } \\
\text { Grey } \\
\text { Grey } \\
\text { Black } \\
\text { Black } \\
\text { Black } \\
\text { Grey" } \\
\text { Black } \\
\text { Grey } \\
\text { Black } \\
\text { Black } \\
\text { Grey } \\
\text { Black } \\
\text { Grey }\end{array}$ & $\begin{array}{l}0.58 \\
0.74 \\
0.75 \\
0.01 \\
0.01 \\
0.01 \\
0.01 \\
0.33 \\
0.44 \\
0.58 \\
0.01 \\
0.45 \\
0.01 \\
0.67 \\
0.46 \\
0.02 \\
0.39 \\
0.02\end{array}$ & $\begin{array}{l}0.30 \\
0.22 \\
0.81 \\
1.99 \\
1.59 \\
1.40 \\
1.82 \\
0.30 \\
0.20 \\
0.44 \\
2.52 \\
0.16 \\
1.68 \\
0.80 \\
0.26 \\
1.75 \\
0.46 \\
1.56\end{array}$ & $\begin{array}{l}6 \cdot 13 \\
7 \cdot 10 \\
6 \cdot 47 \\
6 \cdot 42 \\
6 \cdot 27 \\
5 \cdot 19 \\
6 \cdot 31 \\
5 \cdot 18 \\
5 \cdot 89 \\
5 \cdot 76 \\
7 \cdot 06 \\
5 \cdot 95 \\
6-11 \\
6 \cdot 46 \\
6 \cdot 35 \\
6 \cdot 34 \\
6 \cdot 75 \\
5 \cdot 60\end{array}$ & $\begin{array}{l}0.56 \\
0.58 \\
0.60 \\
0.59 \\
0.77 \\
0.77 \\
0.52 \\
0.59 \\
0.49 \\
0.71 \\
0.59 \\
0.60 \\
0.58 \\
0.68 \\
0.63 \\
0.62 \\
0.73 \\
0.87\end{array}$ \\
\hline
\end{tabular}

The core was taken at $43 \cdot 0^{\circ} \mathrm{N}, 35 \cdot 5^{\circ} \mathrm{E}$, water depth $2,179 \mathrm{~m}$. Percentages refers to the sum of pyrite iron and that soluble during boiling for 1 min in $12 \mathrm{~N} \mathrm{HCl}$.

Present day Black Sea water, which contains about $18 \mathrm{mmoles} / 1$. dissolved sulphate, represents a mixture of fresh water derived from inflowing rivers with a high pro. portion of scewater derived from the Sea of Marmara by way of the Bosporus. The sulphato is derived almost entirely from seawater, which contains about 28 mmoles/l. as compared with the rivers, which contain, on avorage, only 0.35 mmolos/l.8. Because of the high contribution of seawater sulphate, black FeS minerals in the present deep water sediments are completely converted to pyrit $\mathrm{e}^{\dot{\omega}}$, resulting in grey sediment which is similar to the buried grey layers described in Table 1. During the Pleistocenc. when the worldwide sea level was sufficiently lowered below the Bosporus so that seawater inflow was excluded from the Black Sea, the constant influx of river water could have flushed out pre-cxisting sea salts, eventually xesulting in a brackish or fresh bottom water low in tissolved sulphate. During these periods of maximum sea level lowering the black layers may have been deprsited. Whenever the sea levol rose high enough for scawater t" spill over the Bosporus sill, an influx of sulphate to th" deep water would occur and black iron sulphides formed at. at the same time could be completely conrerted to prrits resulting in grey sediment. Thus it is possible that sediment sections containing many black layers record periods of glacial maxima. (The simultaneous change in sea level and appearance of each black layer would not be expected because of complications arising from the interaction of seawater and freshwater in the Bosporus and from tim." lags from rates of mixing of the two water types within the? Black Sea itself.)

This suggestion must await detailed comparison of the age, thickness and frequency of black layers in undist urbed sections of deep Black Sea sediments with other indieators of Pleistocene sea level change. Preliminary examination of cores from the Black Sca deep basin suggest. that the black layers are confined to an overall depth range of approximately the same age span as the last inajor glaciation. In addition, Markov et al. ${ }^{7}$ state that during the last major glaciation, the shallow waters of the Blacki Sea, as inferred from faunal evidence, were very dilute with salinities of less than 5 parts per thousand, which corrt)sponds to less than $4 \mathrm{~mm}$ moles/l. dissolved sulphate. At certain times, the deep water was probably similarly dilut? which enabled formation of the black layers.

I thank the Woods Hole Oceanographic Institution firr providing Black Sea sediment samples and J. Hunt, I). Ross, and R. F. Flint for their assistance and helpfirl discussions. I received grants from the Alfred P. Sloan Foundation and the National Scionce Foundation.

ROBEhT A. BERNER

Department of Geology and Geophysies,

Yale University,

New Haven, Connecticut 06520.

Received MIay 11; revised May 25, 1970.

1 Berner, R. A., Amer. J. Sci., 265, 773 (1967).

2 Berner, R. A., Amer. J. Sci., 268, 1 (1970).

3 Van Straaten, L. M. J. U., heid. Geol. Meded., 19, 1 (1954).

- Voikor, I. 1., Trudy Inst. Okeanol., 50, 68 (1981).

s Ostroumov, E. A., Yolkov, I. I., and Fomina, L. C., Trudy Inst. Okeanol. 50,98 (1961).

- Skopintsev, B. A., Okeanologya, 8, 412 (1968).

'Markov, K. K.. Lazukov, G. I., and Nikolayv, V. A., The Quatsinury Period:

F, II, The Territory of the U'SSR (Moscov Univ., 1065).

\section{Photosensitized Oxidation of Ammonia by Singlet Oxygen in Aqueous Solution and in Seawater}

THE rarious forms of inorganic nitrogen in seal":izu. undergo coinplex transformations involving a rari.ty of biological, chemical and photochemical proeesses which are important for protein synthesis and which determine the development of the marine ecosystem ${ }^{1}$.

But the process involving nitrification of ammonia to nitrite and nitrate by chemicel mechenisms is still $11, t$ clearly" understood.

Swallow ${ }^{2}$ has recently shown that short lived chemical species such as hydrated electrons can play an important part in seawater processes. Singlet oxygen is another 